PRINSIP-PRINSIP PERKAWINAN

\title{
(Analisis Filosofis Implementasi dalam Meminimalisir Angka Perceraian)
}

\author{
Mohamad Rana, Usep Saepullah, \\ Program Doktoral (S3) Program Studi Hukum Keluarga PPs. \\ Universitas Islam Negeri Sunan Gunung Djati Bandung. \\ Email:mohamadrana85@yahoo.com.usepsaepullah72@uinsgd.ac.id
}

\begin{abstract}
ABSTRAK
Perkawinan merupakan sunnatullāh yang berlaku atas makhluk-Nya, tidak terkecuali manusia. Namun Allah Swt.,menggariskan aturan bagi manusia untuk melampiaskan hasrat sexualnya guna rasa ketenangan (sakinah) dan mencurahkan rasa kasih dan sayang kepada pasangannya melalui lembaga perkawinan yang telah ditetapkan-Nya. Dalam pembentukan keluarga, Islam sendiri menggariskan hakikat perkawinan yang disyari'atkannya sebagai upaya terwujudnya sakinah, mawaddah, dan rahmah. Ada sedemikian prinsip-prinsip yang tertuang didalam an-nushus al-muqaddasah sebagai pedoman manusia untuk menciptakan dan mewujudkan tatanan keluarga sebagaimana yang telah digariskan al-Qur'an tersebut.
\end{abstract}

Kata kunci: Prinsip Perkawinan, Islam, Al-Qur'an

\section{ABSTRACT}

Marriage is a sunnatullāh that applies to His creatures, including humans. However, Allah Most High, outlined rules for humans to vent their sexual desires for a sense of tranquility (sakinah) and pour out love and affection for their partners through the institution of marriage that He has established. In the formation of a family, Islam itself outlines the nature of marriage which it expresses as an effort to realize sakinah, mawaddah, and rahmah. There are such principles contained in an-nushus al-muqaddasah as human guidance to create and realize the family order as outlined in the Koran.

Keywords: Principles of Marriage, Islam, Al-Qur'an 


\section{A. PENDAHULUAN}

Al-Qur'an menggariskan perkawinan sebagai kerangka memperoleh sakinah dengan memberdayakan potensi mawaddah dan rahmah yang Allah Swt.,berikan kepada manusia. Ketercapaian hakikat perkawinan tersebut tidak datang secara tiba-tiba, setiap pasangan diharuskan berusaha mewujudkannya dengan pedoman-pedoman yang tertuang dalan an-nușūs al-muqaddasah. Pedoman tersebut merupakan serangkaian prinsip-prinsip perkawinan yang apabila diimplementasikan dalam kehidupan rumah tangga, maka tujuan perkawinan yang digariskan al-Qur'an dapat tercapai, sebagaimana yang telah diteladankan oleh Nabi Saw.

Lantas, apa yang menjadi prinsip-prinsip perkawinan tersebut?, dan bagaimana peranannya dalam upaya meminamilisir angka perceraian?. Untuk menjawab pertanyaanpertanyaan tersebut, maka dalam makalah ini penulis mengkajinya dari berbagai literatur pustaka dan menjadikannya sebagai pisau pada dalam realitas perkawinan yang terjadi dilapangan.

\section{B. METODOLOGI PENELITIAN}

Penelitian ini merupakan jenis penelitian normatif berbasis kajian kepustakaan (library research) dengan mengkaji pembahasan yang diangkat melalui berbagai sumber literatur. Adapun pendekatan yang digunakan dalam penelitian ini menggunakan pendekatan yuridis empiris. Yang dimaksud dengan metode yuridis empiris adalah penelitian hukum mengenai pemberlakuan dan aplikasi ketentuan hukum normatif secara in action pada setiap peristiwa diharapkan berlangsung secara sempurna apabila rumusan ketentuan hukum normatifnya jelas dan tegas serta lengkap.

\section{STUDI LITERATUR}

Kajian tentang pernikahan memang sudah banyak dibahas dalam berbagai publikasi baik berupa buku, penelitian ilmiah, maupun artikel ilmiah dari berbagai aspek dan sudut pandang. Akan tetapi pembahasan tersendiri terkait prinsip-prinsip perkawinan, dapat dikatakan masih sangat jarang. Diantara karya-karya ilmiah yang memiliki keterkaitan dengan penelitian yang penulis angkat diantaranya adalah sebagai berikut:

Artikel ilmiah yang ditulis oleh Rustam Dahar Karnadi Apollo Harahap dengan judul "Kesetaraan Laki-Laki dan Perempuan dalam Hukum Perkawinan Islam". Dari hasil penelitiannya diungkapkan bahwa bahwa perkawinan merupakan sebuah kontrak antara dua orang pasangan yang terdiri dari seorang laki-laki dan seorang perempuan dalam posisi yang setara. Seorang perempuan sebagai pihak yang sederajat dengan laki-laki dapat menetapkan syarat-syarat yang diinginkan sebagaimana juga laki-laki. Perkawinan secara mendasar berarti melibatkan diri dengan pembicaraan mengenai kasih sayang (mawaddah wa rahmah), dan hal inilah yang merupakan pokok pondasi suatu perkawinan. Dengan demikian hubungan antara suami dan isteri adalah hubungan horizontal bukan hubungan vertikal, sehingga tidak terdapat kondisi yang mendominasi dan didominasi. Semua pihak setara dan sederajat untuk saling bekerja sama dalam sebuah ikatan cinta dan kasih sayang.

Mohammad R. Hasan dalam artikel ilmiahnya yang berjudul "Kajian Prinsip Perkawinan Menurut Uu No. 1 Tahun 1974 dalam Perspektif Hukum Islam”. Dari hasil penelitiannya diungkapkan bahwa bahwa Prinsip perkawinan yang hidup dan tumbuh di masyarakat menurut UU No. 1 Tahun 1974 disyaratkan adanya persetujuan dari kedua belah pihak (calon mempelai), sebagai syarat/peminangan, pemberian mahar, dalam akad nikah, disaksikan oleh 2 (dua) orang saksi, wali dari pihak, calon mempelai perempuan dan setiap perkawinan dicatat menurut peraturan perundang-undangan yang berlaku..

Qurrotul Ainiyah dalam artikel ilmiahnya yang berjudul "Prinsip Pernikahan dalam CEDAW Perspektif Hukum Islam". Dari hasil penelusurannya diungkapkan bahwa dalam pasal 16 CEDAW (Konvensi PBB tentang penghapusan segala bentuk diskrimasi terhadap perempuan) yang mengatur tentang hak dan kewajiban yang sama antara laki-laki dan perempuan dalam pernikahan yang berlandaskan pada prinsip kesetaraan (equality) dan keadilan (equity). Isi Pasal 16 tersebut 
kemudian dianalisa dengan prinsip pernikahan Islam. Maka didapatlah simpulan bahwa penjabaran prinsip pernikahan Islam telah menempatkan laki-laki (suami) dan perempuan (isteri) sebagai hamba Allah Swt.,yang mempunyai hak dan kewajiban yang proporsional, tidak harus sama, karena keduanya mempunyai hak dan kewajiban yang berbeda dari jenisnya tetapi akan sama nilainya yaitu nilai penghambaan kepada Allah Swt.,sebagai konsekuensi logis dari "perjanjian kuat" dengan Allah Swt.

\section{HASIL DAN PEMBAHASAN}

\section{Mengurai Makna Perkawinan Etimologi Perkawinan}

Ada dua istilah yang sering digunakan dalam membicarakan relasi pria dan wanita yang dibalut nilai-nilai agama, yaitu "perkawinan" dan "pernikahan", kedua istilah tersebut lumrah digunakan dalam konteks sehari-hari. Walau secara sekilas kedua istilah tersebut memiliki makna yang sama, namun terdapat sisi perbedaan diantara keduanya. Menurut Moh. Zahid bahwa "perkawinan" berasal dari kata "kawin", yang menurut bahasa, artinya membentuk keluarga dengan lawan jenis; melakukan hubungan kelamin dan bersetubuh". Istilah "kawin" digunakan secara umum, untuk tumbuhan, hewan dan manusia, dan menunjukkan proses generatif secara alami. Berbeda dengan itu, istilah "nikah" hanya digunakan pada manusia karena mengandung keabsahan secara hukum nasional, adat istiadat, dan terutama menurut agama. ${ }^{1}$

Berbeda halnya dengan Kamal Mukhtar sebagaimana yang dikutip oleh Muhammad Yunus Shamad, bahwa istilah "nikah" digunakan dalam literatur fiqih, sedangkan dalam konteks ke-Indonesia-an, istilah yang digunakan adalah perkawinan. ${ }^{2}$ Dengan demikian, terlepas dari perluasan dan

${ }^{1}$ Lihat, Moh Zahid, Dua Puluh Lima Tahun Pelaksanaan Undang- Undang Perkawinan, (Jakarta: Departemen Agama RI Badan Litbang Agama dan Diklat Keagamaan, 2002), 2.

2 Lihat, Muhammad Yunus Shamad, "Hukum Pernikahan Dalam Islam”, Istiqra' 5:1 (September 2017), 74-77. penyempitan istilah "perkawinan" dan "pernikahan", serta asal kedua istilah tersebut digunakan, sejatinya esensi dari kedua istilah tersebut adalah sama dari sisi kebahasaannya, yakni berkaitan dengan hubungan biologis antara pria dan wanita.

Perkawinan dalam bahasa Arab berarti "nikāh" atau "zawājj". Makna dasar kedua istilah tersebut menurut M. Quraish Shihab adalah "penyatuan" dan "keberpasangan". Dengan nikāh diharapkan jiwa raga, cita-cita, dan harapan, upaya dan kesungguhan suami istri menyatu karena mereka telah dinikahkan. Akan tetapi, penyatuan kedua insan berbeda jenis tersebut bukan peleburan, karena masingmasing memiliki kepribadian dan identitasnya, sehingga pada hakikatnya mereka menjadi pasangan yang tidak dapat berfungsi kecuali bila bersama pasangannya. ${ }^{3}$

Secara etimologis, kata "nikāh" berarti "ad-damm" (himpunan), “al-jam'u” (kumpulan), atau "al-wat' u” (hubungan intim). Kata "ad-damm" terambil dari akar kata ضميضم- ضما (damma - yadummu - damman) yang berarti mengumpulkan, memegang, menggenggam, menyatukan, menggabungkan, menyandarkan, merangkul, memeluk dan menjumlahkan. Juga berarti bersikap lunak dan ramah $^{4}$.

Sedangkan "al-jam'u” berasal dari akar kata جمع- يجمع- جمعا (jama'a - yajma'u - jam'an) berarti: mengumpulkan, menghimpun, menyatukan, menggabungkan, menjumlahkan dan menyusun. Itulah sebabnya mengapa bersetubuh atau bersenggama dalam istilah fiqih disebut dengan al-jim $\bar{a}^{\prime}$ mengingat persetubuhan secara langsung mengisyaratkan semua aktivitas yang terkandung dalam maknamakna harfiah dari kata al-jam'u. ${ }^{5}$ Istilah $A l$ wat'u berasal dari kata وطأ- بطأ- وطأ (watita yața'u - wat'an), yang berarti berjalan di atas,

3 M. Quraish Shihab, Pengantin al-Qur'an: Kalung Permata Buat Ank-Anakku, (Jakarta: Lentera Hati, 2007), 62.

4 Muhammad Amin Suma, Hukum Keluarga Islam di Dunia Islam, (Jakarta: PT.Raja Grafindo Persada, 2004), 42-43.

5 Muhammad Amin Suma, Hukum Keluarga Islam di Dunia Islam, 42-43. 
melalui, memijak, menginjak, memasuki, menaiki, menggauli dan bersetubuh atau bersenggama. $^{6}$

Menurut ahli uṣul dan bahasa, "bersetubuh" merupakan makna hakiki dari nikah, sementara akad merupakan makna majāzì. Dengan demikian, jika dalam ayat alQur'an atau hadis Nabi Saw., muncul lafaz nikăh dengan tanpa disertai indikator apa pun, berarti maknanya adalah bersetubuh ${ }^{\text {, }}$, sebagaimana QS. al-Nisā'/4:22:

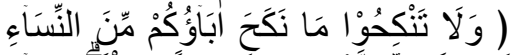

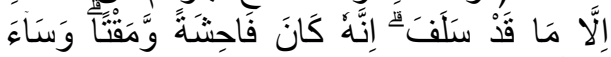

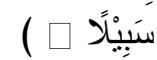

$$
\begin{aligned}
& \text { ( النساءء/42: }
\end{aligned}
$$

"Dan janganlah kamu menikahi perempuan-perempuan yang telah dinikahi oleh ayahmu, kecuali (kejadian pada masa) yang telah lampau. Sungguh, perbuatan itu sangat keji dan dibenci (oleh Allah) dan seburuk-buruk jalan (yang ditempuh). (QS. An-Nisa'/4:22)

Ayat tersebut menurut pemahaman kelompok ini, menunjukkan keharaman seseorang menikahi wanita yang sudah berzina dengan bapaknya. Sementara itu, keharaman menikahi wanita yang sudah menikah (akad) dengan bapaknya ditetapkan berdasarkan ijma'.

Berbeda dengan pandangan di atas, menurut ahli fiqh, makna hakiki nikah adalah "akad", sementara makna majāzi-nya adalah bersetubuh, karena makna itulah yang masyhur dalam al-Qur'an dan hadis. ${ }^{9}$ Ulama Syafi'iyyah dan Malikiyyah memperkuat pendapat kedua ini dengan beberapa argumen ${ }^{10}$, baik dari alQur'an maupun hadis Nabi Muhammad Saw:

6 Ahmad Warson Al-Munawwir, Kamus AlMunawwir Arab-Indonesia Terlengkap, (Yogyakarta: Pustaka Progressif, 1997), 1461.

7 Wahbah al-Zuhāilī, al-Fiquh al-Islāmī wa Adillatuh, vol. 9, (Damaskus: Dār al-Fikr, 2004), 6514.

8 Wahbah al-Zuhāilī, al-Fiquh al-Islāmī wa Adillatuh, 6514.

9 Wahbah al-Zuhāilī, al-Fiqh al-Islāmī wa Adillatuh, 6514.

10 Abd al-Raḥmān al-Jazīrī, Al-Fiqh 'alā alMadhāhib al-Arba'ah, vol. 4, (Beirut: Dār al-Kutub al-'Ilmiyah, 2011), 7.
1. Al-Qur'an

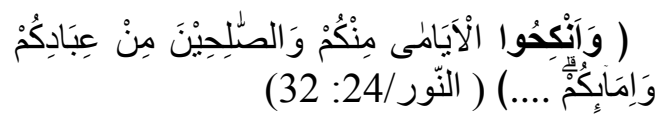

"Dan nikahkanlah orang-orang yang masih membujang di antara kamu, dan juga orang-orang yang layak (menikah) dari hamba-hamba sahayamu yang laki-laki dan perempuan... (QS. AnNūr/24:32)

$$
\begin{aligned}
& \text { 2. Hadiṣ Nabi Saw.,: }
\end{aligned}
$$

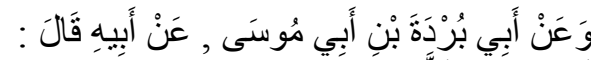

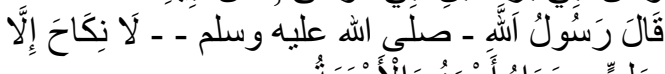

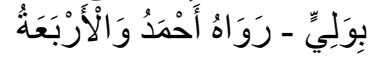

Dari Abu Burdah Ibnu Abu Musa, dari ayahnya Radliyallaahu 'anhu bahwa Rasulullah Shallallaahu 'alaihi wa Sallam bersabda: "Tidak sah nikah kecuali dengan wali." Riwayat Ahmad dan Imam Empat. Hadis shahih menurut Ibnu alMadiny, Tirmidzi, dan Ibnu Hibban. Sebagian menilainya hadis mursal. ${ }^{11}$

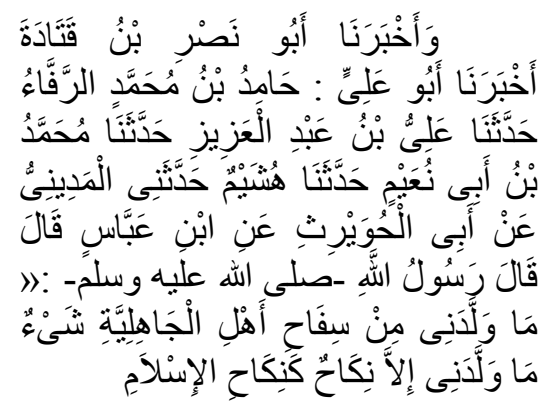

"Mengabarkan kepada kami Abū Naṣr bin Qatādah, mengabarkan kepada kami Abū 'Āliy: Hāmid bin Muhammad ar-Rafā' menceritakan kepada kami 'Ali bin Abdul 'Azīz menceritakan kepada kami Muhammad bin Abī Nu'aim, menceritakan kepada kami Husyaim, menceritakan kepadaku al-Madīniyy dari Abi al-Ḥuwayriṣi dari Ibn 'Abbās berkata: Telah bersabda Rasulullah Saw: " $A k u$ tidak dilahirkan dari hasil perzinaan ahli jahiliyah sesuatu (apapun), dan aku tidak dilahirkan melainkan melalui pernikahan seperti nikah dalam Islam."

11 Ibnu Hajar al-'Asqalānī, Bulūghu alMarām, (Surabaya: Maktabah Dar al-Ihya al'Arabiyah, 1352), 383 . 
Kata "nikāḥ" dalam ayat di atas (QS. al-Nūr/24:32) secara jelas menunjukkan makna 'akad' dan tidak mungkin diartikan 'bersetubuh'. Demikian pula dua hadis di bawahnya. Dalam hadis pertama, nikah dihubungkan dengan wali dan saksi, sehingga menunjukkan bahwa makna nikah adalah akad, sebab bersetubuh tidak dihubungkan dengan wali dan saksi. Hadis kedua juga menegaskan makna akad, karena dalam hadis itu menunjukkan bahwa nikah adalah lawannya sifāh sementara sifāh identik dengan bersetubuh (zina). Senada dengan hal tersebut, Wahbah al-Zuhaily lebih cenderung memaknai nikah secara bahasa adalah akad. Pandangan beliau tersebut berlandaskan argumentasi QS. al-Aḥāâ/33:49:

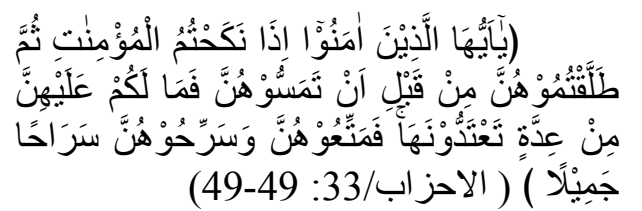

"Hai orang-orang yang beriman, apabila kamu menikahi perempuanperempuan yang beriman, kemudian kamu ceraikan mereka sebelum kamu mencampurinya, maka sekali-sekali tidak wajib atas mereka 'iddah bagimu yang kamu minta menyempurnakannya. Maka berilah mereka mut'ah dan lepaskanlah mereka itu dengan cara yang sebaikbaiknya”.

Menurut al-Zuhaily, ayat di atas adalah ayat menunjukkan bahwa makna hakiki nikah adalah 'akad', sementara 'bersetubuh' adalah makna majāzì-nya (karena ayat di atas menghubungkan 'nikah' dengan talak). Akad disebut "nikah" karena akad-lah yang mengantar kepada 'persetubuhan', sebagaimana al- Qur'an menyebut khamr (الخمر) dengan iṣm/dosa (الإثخ), karena khamr itulah yang mengantar pelakunya mendapatkan dosa. $^{12}$

12 Wahbah al-Zuhaily, al-Tafsìr al-Munīr fi al-'Aqīdah wa al-Shari'ah wa al-Manhaj, vol.22, (Damaskus: al-Fikr al-Mua'āșir, 1418), 54.
Menurut M. Quraish Shihab, al-Qur'an menggunakan kata nikah baik untuk maksud tersebut maupun untuk arti majazi yang diartikan dengan hubungan seks. Beliau menggambarkan nikah sebagai terjadinya hubungan suami-isteri secara syah. ${ }^{13}$

Berbeda halnya dengan ulama Hanafiyyah yang berpendapat bahwa makna hakiki nikah adalah "bersetubuh". ${ }^{14}$ Adapun dasar argumentasi mereka adalah:

Firman Allah Swt.,:

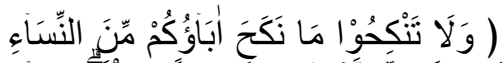

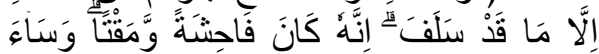

$$
\begin{aligned}
& \text { سَبِيْنَ) } \\
& \text { (النساءء/4: (22) }
\end{aligned}
$$

"Dan janganlah kamu menikahi perempuan-perempuan yang telah dinikahi oleh ayahmu, kecuali (kejadian pada masa) yang telah lampau. Sungguh, perbuatan itu sangat keji dan dibenci (oleh Allah) dan seburuk-buruk jalan (yang ditempuh). (QS. An-Nisā'/4:22)

Nikah yang dimaksud oleh ayat tersebut bukan 'akad', melainkan 'bersetubuh', karena makna وَلَ نَنْكَحُوْا 'pada ayat di atas tidak ada qarinah atau tanda yang menunjukkan makna lain. Disamping itu, berdasarkan sebuah riwayat dari 'Aisyah, ketika isteri Rifa' ah yang telah dicerai tiga oleh suaminya ingin kembali lagi pada Rifa'ah dan ia telah menikah dengan orang lain, namun belum pernah melakukan hubungan suami isteri, lengkapnya dalam riwayat hadits berikut:

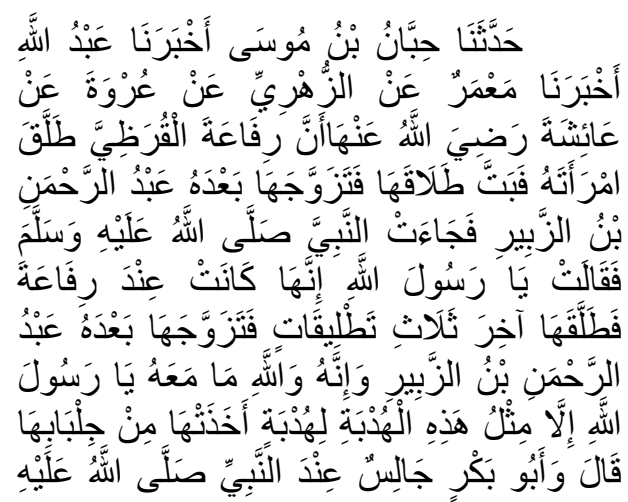

${ }_{13}$ M. Quraish Shihab, Wawasan Al-Qur'an: Tafsir Maudhui atas Pelbagai Persoalan Umat, (Jakarta, Mizan; 1996), 191.

${ }_{14}$ Abd al-Raḥmān al-Jazīīin, Al-Fiqh 'alā alMadhāhib al-Arba'ah, 7. 


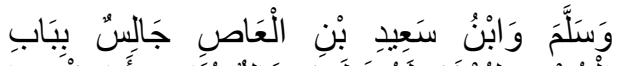

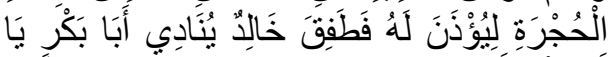

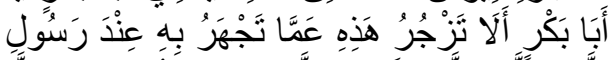

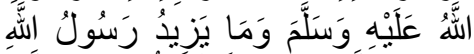

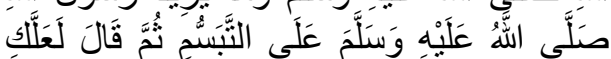

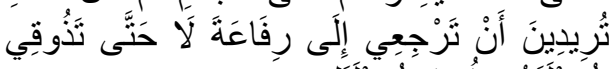

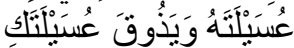

"Menceritakan kepada kami Hibban bin Musa telah mengabarkan kepada kami Abdullah telah mengabarkan kepada kami Ma'mar dari Az Zuhri dari 'Urwah dari Aisyah bahwa Rifa'ah Al Qaradli telah menceraikan isterinya setelah perceraiannya berlalu, Abdurrahman bin Zubair menikahi isterinya Rifa'ah. Lalu isterinya Rifa'ah datang kepada Nabi Saw.,, Aisyah melanjutkan; "Wahai Rasulullah! Sesungguhnya wanita tersebut adalah isterinya Rifa'ah, Rifa'ah menceraikannya hingga jatuh talak tiga. Setelah itu, isterinya Rifa'ah menikah dengan Abdurrahman bin Az Zubair. Dan dia, demi Allah wahai Raulullah, tidaklah bersamanya melainkan seperti ujung kain yang ini." -sambil mengambil ujung jilbabnya- Urwah melanjutkan; "Waktu itu Abu Bakar duduk di sisi Nabi Saw., sementara Khalid bin Sa'id duduk di depan pintu kamar, supaya ia diizinkan masuk, segera ia memanggil Abu Bakar dan berkata; "Wahai Abu Bakar, apakah kamu tidak menghardik apa yang telah ia katakan dengan lancang di sisi Rasulullah Saw?" Rasulullah Saw tersenyum seraya bersabda: "Sepertinya engkau hendak kembali kepada Rifa'ah. Tidak, hingga engkau merasakan madunya Abdurrahman bin $A z$ Zubair dan dia merasakan madumu." (HR. Bukhari)

Dengan demikian, dari perbedaan ulama terhadap makna hakiki dari "nikāh" di atas, penulis dapat menyimpulkan bahwa kecenderungan jumhur ulama dalam memaknai lafal "nikāh" sebagai akad, disamping karena pemahaman mereka terhadap makna nikāh" yang terkandung baik dalam al-Qur'an maupun Hadis, juga karena "bersetubuh" menjadi halal setelah melalui akad, yang didalamnya terdapat ijab dan qabul. Sedangkan pemaknaan "nikāh" sebagai bersetubuh dikalangan Hanafiyah, karena menurut mereka makna itulah dikehendaki oleh teks. Penulis sendiri lebih cenderung pemaknaan "nikāh" sebagai akad, karena adanya akad itulah yang menjadi sebab halalnya bersetubuh dan memunculkan hak dan kewajiban diantara keduanya.

\section{Terminologi Perkawinan}

Secara terminologi para ulama mendefenisikan nikah dengan redaksi yang beragam. Berikut terminologi nikah dikalangan lama madzhab fiqih.

1. Mażhab Hanafiyah:

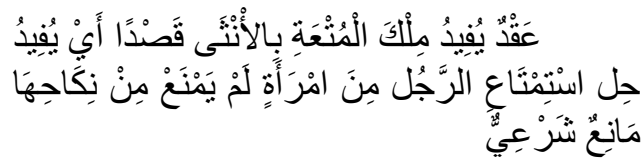

"Akad yang berarti mendapatkan hak milik untuk melakukan hubungan seksual dengan seorang wanita yang tidak ada halangan untuk dinikahi secara syar'i.",

2. Mażhab Al-Malikiyah:

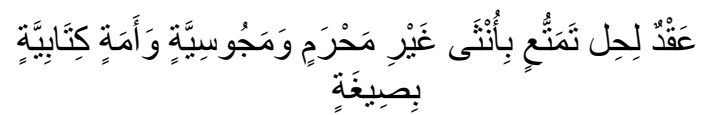

"Sebuah akad yang menghalalkan hubungan seksual dengan wanita yang bukan mahram, bukan majusi, bukan budak ahli kitab dengan shighah."

3. Mażhab Syafi'iyyah:

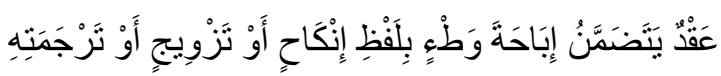

"Akad yang mencakup pembolehan melakukan hubungan seksual dengan lafadz nikah, tazwij atau lafadz yang maknanya sepadan."

\section{Mażhab Al-Hanabilah}

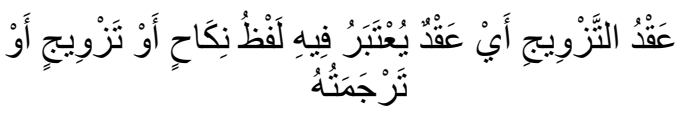

"Akad perkawinan atau akad yang diakui di dalamnya lafadz nikah, tazwij dan lafadz yang punya makna sepadan."

Definisi jumhur ulama menekankan pentingnya menyebutkan lafal yang dipergunakan dalam akad nikah tersebut, yaitu harus lafal nikah, kawin atau yang semakna dengan itu. Dalam definisi ulama Mazhab 
Hanafi maupun Maliki, hal ini tidak diungkapkan secara jelas, sehingga segala lafal yang mengandung makna halalnya seorang laki-laki dan seorang wanita melakukan hubungan seksual boleh dipergunakan, seperti lafal hibah. Yang dapat perhatian khusus bagi ulama Mazhab Hanafi maupun Maliki, disamping masalah kehalalan hubungan seksual, adalah tidak adanya halangan syara' untuk menikahi wanita tersebut. Wanita itu bukan mahram (dan bukan pula penyembah berhala. Menurut jumhur ulama, hal-hal seperti itu tidak dikemukakan dalam definisi mereka karena hal tersebut cukup dibicarakan dalam persyaratan nikah.

Sedangkan yang dimaksud hak milik sebagaimana yang terdapat dalam definisi nikah yang diberikan ulama Hanafiyyah, ialah milku al-intifa', yaitu hak milik penggunaan (pemakai) sesuatu benda, karena itu akad nikah tidak menimbulkan milku ar-raqabah, yaitu memiliki sesuatu benda, sehingga dapat dialihkan kepada siapapun; juga bukan milku al-manfa'ah, yaitu hak memiliki kemanfaatan sesuatu benda, yang dalam hal ini manfaatnya boleh dialihkan kepada orang lain. ${ }^{15}$

Dari definisi perkawinan yang diberikan ulama fikih di atas, mayoritas cenderung mendefinisikan perkawinan hanya sebagai "sarana untuk dibolehkannya melakukan hubungan suami istri", definisi tersebut cenderung bersifat sexual oriented dan berbeda dengan konsep perkawinan yang digariskan alQur'an sebagai miṣāqan ghaliża. Hal ini dapat dimaklumi, karena menurut penulis, definisi yang diberikan oleh ulama madzhab fikih di atas tidak terlepas dari makna asal kata "nikāḥ" itu sendiri sebagai "hubungan seksual".

Definisi yang lebih dalam terkait perkawinan dapat kita dapati dari uraian definisi para ulama kontemporer seperti Syaikh Abu Zahrah dan Dr. Ahmad Ghandur. Syaikh Abu Zahrah memberikan definisi perkawinan sebagai:

"Akad yang menjadikan halalnya hubungan seksual antara seorang lelaki

15 Ahmad Atabik dan Khoridatul Mudhiiah, "Pernikahan Dan Hikmahnya Perspektif Hukum Islam”, Yudisia 5: 2 (Desember 2014), 286-316. dan seorang wanita, saling tolong menolong di antara keduanya serta menimbulkan hak dan kewajiban di antara keduanya". 16

Dengan redaksi yang berbeda namun memiliki esensi sama, Dr. Ahmad Ghandur mendefinisikan perkawinan sebagai:

"Akad yang menimbulkan kebolehan bergaul antara laki-laki dan perempuan dalam tuntutan naluri kemanusiaan dalam kehidupan, serta menjadikan antara kedua pihak secara timbal balik hak-hak dan kewajiban-kewajiban" ${ }^{\text {"17. }}$

Sedangkan dalam Pasal 2 Kompilasi Hukum Islam disebutkan:

"Pernikahan yaitu akad yang sangat kuat atau mīṣāaan ghalīżan untuk mentaati perintah Allah dan melaksanakannya merupakan ibadah."

Dari beberapa definisi berkaitan dengan perkawinan yang diberikan oleh ulama kontemporer di atas memandang perkawinan tidak hanya sebagai wașilah untuk kebolehan melakukan hubungan seksual semata, namun mengakibatkan adanya hak dan kewajiban secara seimbang diantara suami-istri dan saling tolong menolong serta melengkapi antara keduanya.

\section{E. ANJURAN MENIKAH}

Sebagai agama fitrah, tuntutan Islam selalu sejalan dengan fitrah kemanusiaan yang menilai bahwa lembaga perkawinan merupakan cara hidup yang wajar. Karena itu, ketika ada beberapa sahabat Nabi Saw., bermaksud melakukan sesuatu yang tidak sejalan dengan fitrah kemanusiaan, Beliau menegur mereka dengan menyatakan bahwa beliau pun menikah $^{18}$, hal ini sebagaimana yang dijelaskan dalam sebuah Hadiṣ yang diriwayatkan oleh Imam Muslim:

16 Abdul Azis Dahlan, et.al, Ensiklopedi Hukum Islam, Jilid 4, (Jakarta: Ichtiar Baru van Hoeve, 1996), 1329.

17 Ahmad Al Ghandur, Al-Ahwwāl AlSyakhșiyyah fī al-Tasyrī' al-Islāmy, Cet.-5, (Kuwait: Maktabah Al Falāh, 2006), 33.

18 M. Quraish Shihab, Pengantin al-Qur'an: Kalung Permata Buat Ank-Anakku, (Jakarta: Lentera Hati, 2007), 55. 


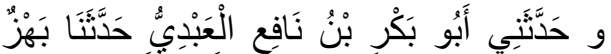

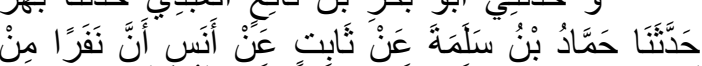

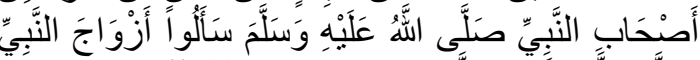

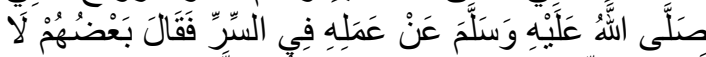

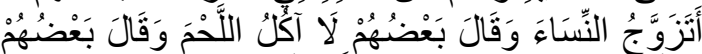

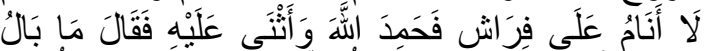

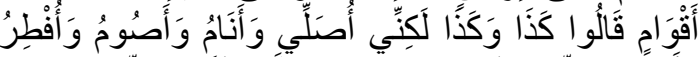

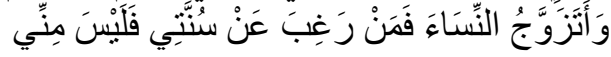

"Dan telah menceritakan kepadaku [Abu Bakar bin Nafi' Al Abdi] telah menceritakan kepada kami Bahz telah menceritakan kepada kami Hammad bin Salamah dari Tsabit dari Anas bahwa sekelompok orang dari kalangan sahabat Nabi shallallahu 'alaihi wasallam bertanya kepada isteri-isteri Nabi shallallahu 'alaihi wasallam mengenai amalan beliau yang tersembunyi. Maka sebagian dari mereka pun berkata, "Saya tidak akan menikah." Kemudian sebagian lagi berkata, "Aku tidak akan makan daging." Dan sebagian lain lagi berkata, "Aku tidak akan tidur di atas kasurku." Mendengar ucapan-ucapan itu, Nabi Saw., memuji Allah Swt.,dan menyanjung-Nya, kemudian beliau bersabda: "Ada apa dengan mereka? Mereka berkata begini dan begitu, padahal aku sendiri shalat dan juga tidur, berpuasa dan juga berbuka, dan aku juga menikahi wanita. Maka siapa yang saja yang membenci sunnahku, berarti bukan dari golonganku." (HR. Muslim) ${ }^{19}$

Dalam sabdanya yang lain, beliau (Nabi Saw.,) bahkan menganjurkan bagi kalangan pemuda dan pemudi untuk bersegera menikah apabila sudah memiliki kemampuan.

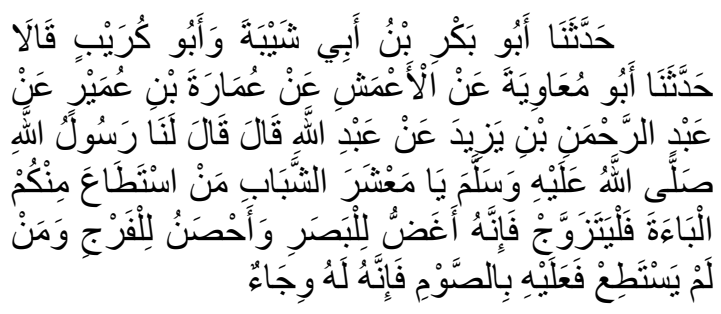

"Telah menceritakan kepada kami Abu Bakr bin Abu Syaibah dan Abu Kuraib keduanya berkata, telah menceritakan kepada kami Abu Mu'awiyah dari Al

19 Abū al-Ḥusaini Muslim bin al-Ḥujāj bin Muslim al-Qasyīri al-Nīsābūri. Shahīh Muslim, (Beirut: Dār al-Kutub al-'Ilmiyah, 1998), 2487.
A'masy dari Umarah bin Umair dari Abdurrahman bin Yazid dari Abdullah ia berkata; Rasulullah Saw bersabda: "Wahai para pemuda, siapa di antara kalian yang telah memperoleh kemampuan menghidupi kerumahtanggaan, kawinlah. Karena sesungguhnya, perhikahan itu lebih mampu menahan pandangan mata dan menjaga kemaluan. Dan, barangsiapa belum mampu melaksanakannya, hendaklah ia berpuasa karena puasa itu akan meredakan gejolak hasrat seksual." (HR. Muslim) ${ }^{20}$

Allah Swt.,memerintahkan kepada orang tua/ atau wali untuk mendukung dan merestui keinginan menikah anak-anak mereka, dan tidak terlalu mempertimbangkan kemampuan materi calon pasangan, namun dalam saat yang sama juga memerintahkan mereka yang tidak memiliki kemampuan material untuk menahan diri dan memelihara kesuciannya. Firman Allah Swt.,:

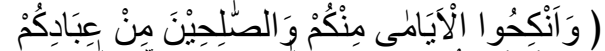

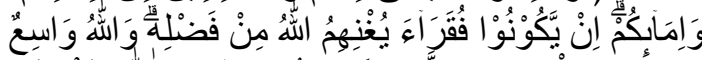

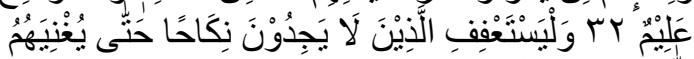

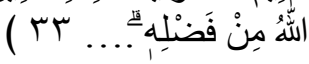

$$
\begin{aligned}
& \text { (النّور/24: 32-32) }
\end{aligned}
$$

"Dan nikahkanlah orang-orang yang masih membujang di antara kamu, dan juga orang-orang yang layak (menikah) dari hamba-hamba sahayamu yang lakilaki dan perempuan. Jika mereka miskin, Allah akan memberi kemampuan kepada mereka dengan karunia-Nya. Dan Allah Mahaluas (pemberian-Nya), Maha Mengetahui. Dan orang-orang yang tidak mampu menikah hendaklah menjaga kesucian (diri)nya, sampai Allah memberi kemampuan kepada mereka dengan karunia-Nya...(QS. An-Nūr/24:32-33)

Baik al-Qur'an maupun Hadis menganjurkan pernikahan dan menjadikan pernikahan sebagai satu-satunya jalan bagi pemuasan naluri biologis. Islam menganjurkan masyarakat untuk melangsungkan pernikahan antara laki-laki dan perempuan yang belum menikah dan mewajibkan orang-orang yang

${ }^{20}$ Abū al-Husaini Muslim bin al-Hujāj bin Muslim al-Qasyīri al-Nīsābūri, Shahīh Muslim, 2486. 
belum menikah untuk memelihara kesuciannya. Namun dalam hal ini, Nabi Saw., memberikan pedoman kriteria pasangan yang hendak dinikahi, hal ini sebagaimana hadiṣ yang diriwayatkan oleh Imam Bukhari:

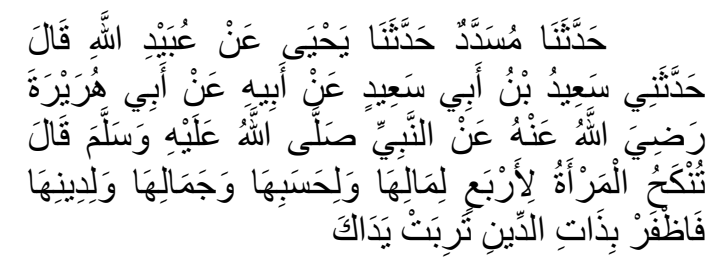

"Telah menceritakan kepada kami Musaddad. Telah menceritakan kepada kami Yahya dari Ubaidullah ia berkata; Telah menceritakan kepadaku Sa'id bin Abu Sa'id dari bapaknya dari Abu Hurairah O, dari Nabi Saw.,, beliau bersabda: "Wanita itu dinikahi karena empat hal, karena hartanya, karena keturunannya, karena kecantikannya dan karena agamanya. Maka pilihlah karena agamanya, niscaya kamu akan beruntung." (HR. Bukhari) $^{21}$

Dari sabda Nabi Saw., di atas, timbul suatu pertanyaan dari penulis, mengapa Nabi Saw., dalam sabdanya tersebut menjadikan kriteria "agama" berada dalam urutan terakhir?, serta mengapa sabda beliau i tersebut hanya ditujukan kepada kaum laki-laki dalam memilih wanita sebagai pasangan hidupnya, bukankah perempuan juga memiliki hak yang sama untuk memilih pasangan hidup, baik dengan menerima maupun menolak pinangan yang datang kepadanya?.

Berkaitan dengan hal tersebut, menurut Nurun Najwah dalam tulisannya yang berjudul "Kriteria Memilih Pasangan Hidup (Kajian Hermeneutika Hadis)", bahwa memahami Hadiṣ Nabi Saw., tersebut tidak bisa dipahami secara lahiriyah semata, namun harus dilihat setting sosial masyarakat Arab kala itu yang menganut sistem patriarkhi, di mana posisi dominan dan penting dipegang oleh laki-laki, bapak (suami). Laki-laki yang bertanggungjawab menjalankan peran publik mencari nafkah untuk kelangsungan hidup, mempertahankan keutuhan keluarga ataupun kabilah, bahkan meningkatkan taraf hidup,

21 Muhammad bin Ismail Abu 'Abdillah alBukhari, Al-Jāmi’ al-Șahīh al-Mukhtașar, (Beirut: Dār Ibn Katsīr, 1987), 4700. yakni dengan memenangkan peperangan dan mendapatkan rampasan perang (ganimah) yang banyak. Sedang perempuan menjalankan peran domestik sebagai pengasuh anak dan pengatur urusan rumah tangga. Konsekuensi dari tanggungjawab yang besar tersebut, menjadikan laki-laki memiliki beberapa hak istimewa. $^{22}$

Tidak terkecuali dalam lembaga perkawinan masyarakat Arab pra Islam, kedudukan perempuan laksana harta benda yang tidak bernialai, seorang perempuan seringkali dieksploitasi dalam bentuk yang sangat tidak manusiawi, seperti dipaksa kawin, diperlakukan semena-mena oleh suami, dipoligami tanpa batas dan tanpa syarat, ditukar, disetubuhi (budak) untuk dijual anaknya. Saat itu, bentuk perkawinan yang paling dominan adalah kontraktual yang terorientasi pada seksual. Seorang suami dibenarkan oleh tradisi untuk saling tukar menukar istri.

Kedudukan perempuan yang direndahkan oleh masayarakat Arab pra Islam pada ujungnya menjadi sebuah budaya yang melekat, dan cenderung mewarnai pandangan laki-laki terhadap perempuan, bahkan setelah Islam datang. Walaupun secara harkat dan martabat seorang perempuan telah diangkat Islam sedemikian tingginya, akan tetapi harus diakui warisan budaya patriarkhi masyarakat Arab pra Islam tersebut tetap masih ada pada masyarakat muslim kala itu, khususnya berkaitan peran dan kedudukan wanita. ${ }^{23}$

22 Nurun Najwah, "Kriteria Memilih Pasangan Hidup (Kajian Hermeneutika Hadis)", Jurnal Studi Ilmu-Ilmu al-Qur'an dan Hadis 17: 1 (Januari 2016), 97-122.

23 Salah satu contoh bahwa budaya patriarkhi masyarakat Arab pra Islam masih turut mewarnai pandangan generasi muslim awal umat Islam terhadap perempuan adalah pada saat turunnya ayat tentang waris. Sebagaimana yang dijelaskan oleh Ibn Kașīr, bahwa turunnya ayat waris tersebut memicu ketidaksukaan pada sebagian kalangan sahabat laki-laki terkait ketentuan pembagian warisan yang telah ditetapkan al-Qur'an. Bahkan terdapat dikalangan sahabat yang a yang mengatakan, "wanita diberi seperempat atau seperdelapan dan anak perempuan diberi setengah serta anak laki-laki kecil pun diberi, padahal tiada salah seorang pun dari mereka 
Oleh karenanya, kondisi historis yang melingkupi masyarakat pada masa Nabi Muhammad Saw, bisa lebih memahamkan kita, mengapa redaksi-redaksi hadis yang ada memberi kesan perempuan sebagai obyek yang dipilih dan pertimbangan fisik menjadi skala prioritas dan bukan sebaliknya, lebih karena kultur masyarakat Arab saat itu membatasi pergaulan laki-laki dan perempuan dengan sangat ketat dan tertututupnya perempuan dengan pakaian yang sangat rapat. Maka faktor melihat calon istri, diharapkan bisa mendorong untuk menikahi perempuan tersebut. Sedangkan beberapa riwayat yang menegaskan anjuran untuk menikahi gadis yang subur, karena nasab, atau harta, semata-mata sebagai bentuk penjelasan dari Nabi Saw., akan realitas umumnya masyarakat Arab memilih pasangannya didasarkan faktor-faktor, dan itu tidak disalahkan oleh Nabi Saw., hanya saja beliau menegaskan bahwa faktor agama jauh lebih baik, sebagai dasar pertimbangan. Dengan beberapa pertimbangan yang diinginkan oleh yang bersangkutan tersebut diharapkan keselarasan dalam berkeluarga lebih mudah tercapai, lebih harmonis, dibanding menikah dengan pasangan yang tidak dikehendaki dan memiliki banyak perbedaan dalam banyak aspek. $^{24}$

Dengan demikian, apabila hadiṣ Nabi Saw., tersebut dipahami dalam konteks saat ini dimana kaum perempuan sudah memiliki kesadaran dalam menuntut kesetaraan hak dengan laki-laki peran, bahkan berperan aktif dalam berbagai aspek dan bidang, maka sabda beliau harus dipahami secara seimbang, atau

yang berperang membela kaumnya dan tidak dapat merebut ghanimah." Akan tetapi hadis ini didiamkan saja; barang kali Rasulullah melupakannya, atau kita katakan kepadanya, lalu beliau bersedia mengubahnya. Mereka berkata, "Wahai Rasulullah, mengapa engkau memberikan harta warisan kepada anak perempuan setengah dari harta yang ditinggalkan ayahnya, padahal ia tidak menaiki kuda dan tidak pula berperang membela kaumnya? bahkan anak kecil pun diberi bagian warisan, padahal ia tidak dapat berbuat apa-apa”. Lihat, Ibn Kasiīr, Tafsīr al-Qurān al'Ażìm, Juz II, (Kairo: Dār al-Hadits, 2010), 224.

24 Nurun Najwah, "Kriteria Memilih Pasangan Hidup (Kajian Hermeneutika Hadis)", Jurnal Studi Ilmu-Ilmu al-Qur'an dan Hadis 17: 1 (Januari 2016), 97-122. meminjam istilah Faqihuddin Abd. Kodir secara mubādalah. Sehingga ketertujuan sabda Nabi Saw., tersebut tidak hanya diperuntukkan laki-laki semata, namun juga perempuan dalam memilih jodohnya.

Dengan demikian dalam memahami hadits Nabi Saw., tersebut menurut Faqihuddin Abd. Qodir bahwa baik bagi laki-laki maupun perempuan dalam memilih jodoh adalah suatu kewajaran dan manusiawi apabila setiap masing-masing individu dalam memilih jodohnya berdasarkan salah satu, atau beberapa hal yang disabdakan Nabi Saw., -faktor ekonomi, sosial, dan biologis--, karena Nabi Saw., sendiri tidak melarangnya dan menganjurkannya. Akan tetapi, faktor agama merupakan pilihan yang terbaik, agar dapat memberi makna terhadap ketiga faktor sebelumnya. Karena dengan faktor agama dapat membuat kehidupan rumah tangga lebih kuat, kokoh, dan tidak mudah goyah, bahkan memiliki makna spiritual yang dalam. ${ }^{25}$

\section{F. HAKIKAT PERKAWINAN}

Perkawinan bukanlah suatu ikatan yang hanya mengikat satu pihak, dan untuk kebahagiaan satu pihak, serta kewajiban satu pihak untuk melanggengkannya. Keberpasangan merupakan realitas ketetapan Ilahi tidak hanya untuk manusia, tetapi semua makhluk hidup, sebagaimana dalam QS. alŻāriyāt/51: $49^{26}$, QS. Yāsīn/36: $36^{27}$, QS. alSyu'arā'/42: $11^{28}$. Ikatan perkawinan-lah yang

25 Lihat, Faqihuddin Abdul Kodir, Qirā'ah Mubādalah: Tafsir Progresif untuk Keadilan Gender dalam Islam, (Yogyakarta: IRCiSoD, 2019), 338-330

${ }^{26}$ Firman Allah Swt:

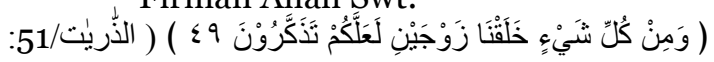

$(49$

"Dan segala sesuatu Kami ciptakan berpasang-pasangan agar kamu mengingat (kebesaran Allah). (QS. al-Żāriyāt/51: 49)

27 Firman Allah Swt:

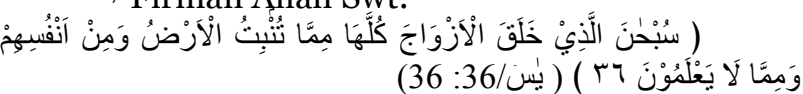

"Mahasuci (Allah) yang telah menciptakan semuanya berpasang-pasangan, baik dari apa yang ditumbuhkan oleh bumi dan dari diri mereka sendiri, maupun dari apa yang tidak mereka ketahui. (QS. Yāsīn/36: 36)

${ }^{28}$ Firman Allah Swt: 
membedakan keberpasangan makhluk manusia dengan makhluk yang lain.

Perkawinan juga bukan semata-mata upaya regenerasi, meskipun al-Qur'an juga mengisyaratkan hal tersebut dalam QS. alSyūrā/42: 11; al-Naḥl/ 16: 72; al-Nisā'/ 4: 1, karena harus dimengerti pemilikan anak tidak menjadi kontrol sepenuhnya manusia. Pernikahan adalah keterikatan dua pihak yang bertransaksi (suami-istri) untuk mewujudkan mahligai rumah tangga yang dilandasi sakinah, mawaddah, dan rahmah dengan ikatan yang kokoh (miṣāqan galīzan). Sebagaimana yang digambarkan secara lugas dalam QS. alRūm/30: 21:

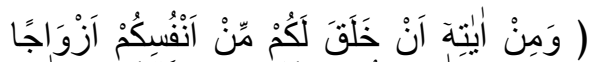

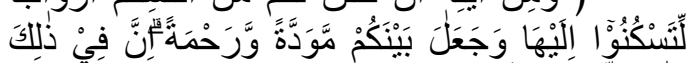

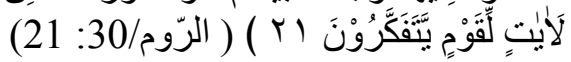
(kebesaran)-Nya ialah Dia menciptakan pasangan-pasangan untukmu dari jenismu sendiri, agar kamu cenderung dan merasa tenteram kepadanya, dan Dia menjadikan di antaramu rasa kasih dan sayang. Sungguh, pada yang demikian itu benarbenar terdapat tanda-tanda (kebesaran Allah) bagi kaum yang berpikir". (QS. ArRūm/30:21)

Kata sakinah disebutkan sebanyak enam kali dalam Al-Qur'an, yaitu pada QS. alBaqarah/2: $248^{29}$, QS. at-Taubah/9: $26^{30}$ dan

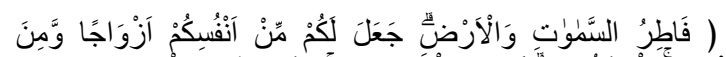

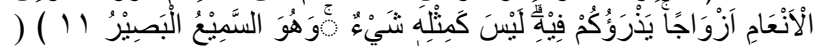

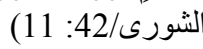

“ (Allah) Pencipta langit dan bumi. Dia menjadikan bagi kamu pasangan-pasangan dari jenis kamu sendiri, dan dari jenis hewan ternak pasangan-pasangan (juga). Dijadikan-Nya kamu berkembang biak dengan jalan itu. Tidak ada sesuatu pun yang serupa dengan Dia. Dan Dia Yang Maha Mendengar, Maha Melihat. (QS. alSyu'arā'/42: 11)

${ }^{29}$ Firman Allah Swt:

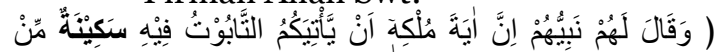

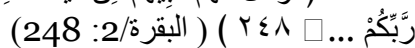

"Dan nabi mereka berkata kepada mereka, "Sesungguhnya tanda kerajaannya ialah datangnya Tabut kepadamu, yang di dalamnya terdapat ketenangan dari Tuhanmu ... (QS. AlBaqarah/2:248)

${ }^{30}$ Firman Allah Swt:
$40^{31}$, QS. al-Fath $/ 48: 4^{32}, 18^{33}$ dan $26^{34}$. Dalam ayat-ayat tersebut dijelaskan bahwa sakinah itu didatangkan Allah Swt.,ke dalam hati para Nabi Saw., dan orang-orang yang beriman agar tabah dan tidak gentar menghadapi tantangan, rintangan, ujian dan cobaan ataupun musibah. Sehingga sakinah dapat juga dipahami dengan "sesuatu yang memuaskan hati". 35

Berdasarkan hasil kajian M. Quraish Shihab, bahwa Kata sakinah terambil dari bahasa Arab yang terdiri dari huruf-huruf sin, kaf, dan nun yang mengandung makna ketenangan atau antonim dari kegoncangan dan

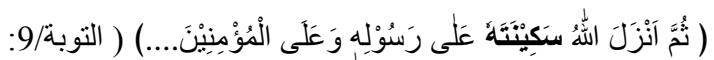

"Kemudian Allah menurunkan ketenangan kepada Rasul-Nya dan kepada orang-orang yang beriman... (QS. At-Taubah/9:26)

${ }^{31}$ Firman Allah Swt:

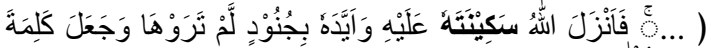

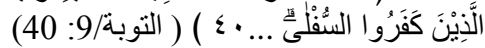

“... Maka Allah menurunkan ketenangan kepadanya (Muhammad) dan membantu dengan bala tentara (malaikat-malaikat) yang tidak terlihat olehmu, dan Dia menjadikan seruan orang-orang kafir itu rendah..." (QS. AtTaubah/9:40)

${ }^{32}$ Firman Allah Swt:

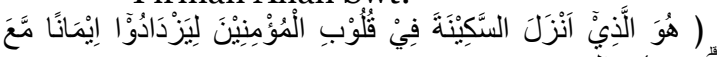

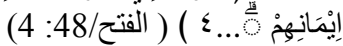
"Dialah yang telah menurunkan ketenangan ke dalam hati orang-orang mukmin untuk menambah keimanan atas keimanan mereka (yang telah ada). Dan milik Allah-lah bala tentara langit dan bumi, dan Allah Maha Mengetahui, Mahabijaksana; (QS. Al-Fath.̣8:4)

${ }^{33}$ Firman Allah Swt:

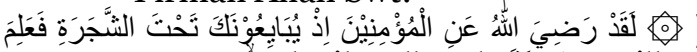

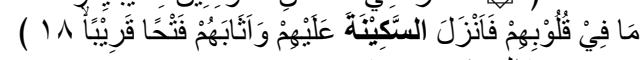
(الفتح/48: (18)

"Sungguh, Allah Swtelah meridai orangorang mukmin ketika mereka berjanji setia kepadamu (Muhammad) di bawah pohon, Dia mengetahui apa yang ada dalam hati mereka lalu Dia memberikan ketenangan atas mereka dan memberi balasan dengan kemenangan yang dekat, (QS. Al-Fath/48:18)

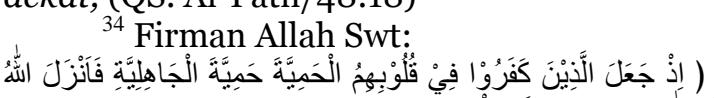

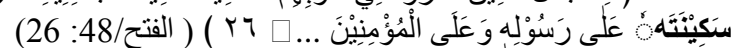

"Ketika orang-orang yang kafir menanamkan kesombongan dalam hati mereka (yaitu) kesombongan jahiliah, lalu Allah menurunkan ketenangan kepada Rasul-Nya, dan kepada orang-orang mukmin...(QS. AlFath/48:26)

35 Zaitunah Subhan, Membina Keluarga Sakinah, (Yogyakarta;Pustaka Pesantren, 2004) 
pergerakan. Berbagai bentuk kata kata yang terdiri dari ketiga huruf tersebut, kesemuanya bermuara pada makna di atas. Misalnya, rumah dinamai maskan karena ia adalah tempat untuk meraih ketenangan setelah penghuninya bergerak, bahkan boleh jadi mengalami kegoncangan di luar rumah. Memang pakarpakar bahasa menegaskan bahwa kata itu tidak digunakan kecuali untuk menggambarkan ketenangan dan ketentraman setelah sebelumnya ada gejolak. Setiap jenis kelaminlelaki atau perempuan, jantan atau betinadilengkapi Allah $\mathrm{T}$ dengan alat serta aneka sifat dan kecenderungan yang tidak dapat berfungsi secara sempurna jika ia berdiri sendiri $^{36}$.

Menarik penjelasan dari Faqihuddin Abdul Kodir, berkaitan dengan QS. ayat diatas (QS. Ar.Rūm/30: 21), bahwa tujuan pernikahan adalah ketenangan yang tidak hanya dirasakan oleh suami, namun juga istri, dengan pondasi rasa dan sikap cinta (mawaddah) dan kasih (rahmah). Ketenangan ini tentu saja dalam berbagai aspek, terutama spiritual, psikologi, ekonomi, serta hubungan personal dan sosial. Ketenangan ini mensyaratkan mawaddah dan rahmah. Mawaddah adalah rasa dan sikap cinta kepada seseorang yang manfaatnya kembali kepada dirinya. Sementara rahmah adalah rasa dan sikap cinta seseorang kepada pasangannya yang membuatnya bergerak untuk membahagiakan pasangannya tersebut. Dengan demikian, baik suami maupun istri, keduanya dituntut aktif membahagiakan pasangannya dengan dorongan rahmah, sekaligus memperoleh kebahagiaan dari pasangannya dengan modal mawaddah. ${ }^{37}$

Dengan demikian, hakikat inti dari perkawinan yang disyari'atkan Islam adalah terwujudnya ketenangan diantara suami maupun istri dengan dihiasi dan diliputi rasa saling kasih mengasihi, cinta mencintai, dan saling menyempurnakan satu sama lainnya. Dengan tercapainya hakikat tersebut, maka setiap problem rumah tangga yang silih berganti datang dan menghampiri akan selalu

${ }_{36}$ M.Quraish Shihab, Pengantin al-Qur'an: Kalung Permata Buat Anak-Anakku, 80.

37 Faqihuddin Abdul Kodir, Qirā'ah Mubādalah, 336-337. mampu dilewati dan dihadapi oleh suami istri secara elegan dan bijaksana, sehingga rumah tangga yang dibina akan semakin kokoh dan bahagia, tidak hanya dari sisi jasmaniah semata, namun juga dari sisi ruhaniyahnya.

\section{G.PRINSIP-PRINSIP PERKAWINAN}

Setiap pasangan suami istri pasti mendambakan mahligai rumah tangga yang dibangunnya selalu rukun, bahagia, dan penuh ketenangan (sakinah) hingga maut memisahkan mereka berdua. Akan tetapi, didalam kehidupan rumah tangga pasti akan selalu ada masalah dan ujian yang menghampiri keduanya. Tidak jarang pasangan suami istri harus mengakhiri biduk rumah tangga yang dibina karena adanya suatu masalah atau ujian yang menimpa keduanya, dan menurut keduanya tiada jalan keluar lain selain kata perpisahan (perceraian). Namun, masih banyak pula pasangan suami istri yang mampu bertahan dan menyelesaikan segala ujian dan masalah yang silih berganti datang, bahkan semakin mengokohkan rumah tangga yang dibangun bersama pasangan.

Islam mensyariatkan perkawinan dalam rangka terwujudnya rasa sakinah, mawaddah, dan rahmah bagi suami maupun istri. Namun ketiganya, sebagaimana yang dikatakan $M$. Quraish Shihab, tidak datang begitu saja, ia harus diusahakan oleh setiap pasangan untuk kehadirannya dalam biduk rumah tangga ${ }^{38}$. Untuk tercapainya tujuan perkawinan yang dikehendaki al-Qur'an, Islam menyiapkan sederet prinsip-prinsip sebagai pegangan setiap pasangan agar tercapainya rasa sakinah, mawaddah, dan rahmah dalam kehidupan rumah tangga yang dibinanya. Sekian banyak prinsip itu adalah sebagai berikut:

\section{Prinsip kebebasan memilih pasangan}

Memilih pasangan merupakan hak dasar yang diberikan Islam tidak hanya bagi laki-laki, namun perempuan pun memiliki hak sama. Menurut Asghar Ali Engineer, bahwa di dalam al-Qur'an perempuan setara dengan laki-laki dalam kemampuan mental dan moralnya,

38 Lihat, M. Quraish Shihab, Perempuan:Dari cinta Sampai Seks, Dari Nikah Mut'ah sampai Nikah Sunnah, Dari Bias Lama sampai Bias Baru, (Jakarta: Lentera Hati, 2007), 141. 
sehingga masing-masing memiliki hak independen yang sama dalam menentukan pasangannya. 39 Oleh sebab itu, Islam menegaskan bahwa perempuan memiliki hak mutlak untuk menerima atau menolak pinangan. Hal ini sebagaimana sebuah riwayat hadiș yang diriwayatkan oleh Ibn Majah.

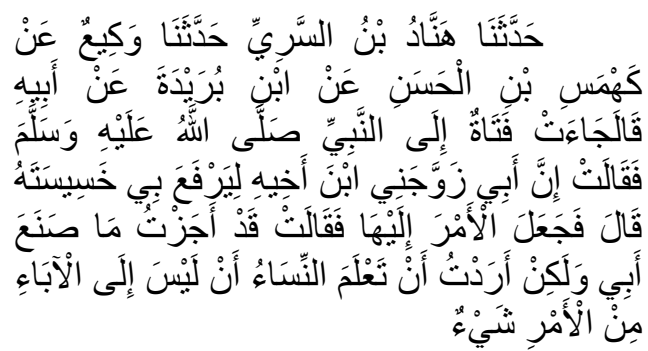

"Telah menceritakan kepada kami Hannad bin As Sarri berkata, telah menceritakan kepada kami Waqi' dari Kahmas bin Al Hasan dari Ibnu Buraidah dari Bapaknya ia berkata: "Ada seorang gadis datang kepada Nabi Saw., dan berkata, "Sesungguhnya ayahku menikahkan aku dengan keponakannya dengan tujuan agar mengangkatnya dari kehinaan." Buraidah berkata, "Maka Beliau menyerahkan urusan itu kepada gadis tersebut. Lalu ia berkata, "Aku telah menerima putusan bapakku, hanya saja aku ingin agar kaum wanita mengetahui, bahwa

39 Dalam konteks ini ia mendasarkan pandangannya tersebut pada QS. al-Ahzāb ayat 35:

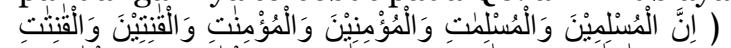

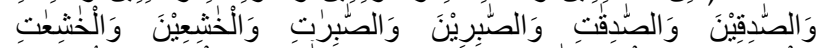

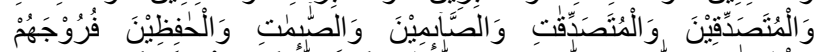

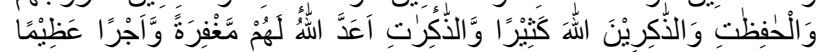

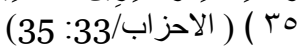

"Sungguh, laki-laki dan perempuan muslim, laki-laki dan perempuan mukmin, laki-laki dan perempuan yang tetap dalam ketaatannya, lakilaki dan perempuan yang benar, laki-laki dan perempuan yang sabar, laki-laki dan perempuan yang khusyuk, laki-laki dan perempuan yang bersedekah, laki-laki dan perempuan yang berpuasa, laki-laki dan perempuan yang memelihara kehormatannya, laki-laki dan perempuan yang banyak menyebut (nama) Allah, Allah Swtelah menyediakan untuk mereka ampunan dan pahala yang besar". (QS. AlAhzāb/33:35). Lihat, Asghar Ali Engineer, Hak-hak Perempuan dalam Islam, terj. Farid Wajidi, (Bandung, LSPPA, 1994), hlm. 137 keputusan bukan ada pada bapak-bapak mereka." (HR.Ibnu Majah).

Dalam konteks ini, kebebasan perempuan dalam memilih pasangan sesuai dengan yang diharapkannya, tidak dimaknai tanpa harus seizin dan ridho wali. Sebab tidak dapat dipungkiri bahwa perkawinan akan lebih sempurna jika kebebasan tersebut dalam waktu yang bersamaan juga diharapkan "memuaskan" (baca: diridhoi dan direstui) oleh orang tua (wali) sebagai pihak yang mengakadkan dirinya dengan calon suami ${ }^{41}$.

\section{Prinsip Kesetaraan}

Perkawinan merupakan sebuah akad antara dua orang pasangan yang terdiri dari seorang laki-laki dan seorang perempuan dalam posisi yang setara. Karena hubungan antara suami dan isteri adalah hubungan horizontal bukan hubungan vertikal, sehingga tidak terdapat kondisi yang mendominasi dan didominasi. Semua pihak setara dan sederajat untuk saling bekerja sama dalam sebuah ikatan cinta dan kasih sayang.

Menurut M. Quraish Shihab, kesetaraan suami dan istri pun dapat dilihat dari segi kejadian keduanya yang tidak memiliki perbedaan apapun. Oleh sebab itu al-Qur'an menegaskan bahwa "sebagian kamu dari sebagian yang lain [ba'dukum $\min$ ba'd]". Istilah ini digunakan untuk menunjukkan kesetaraan/ kebersamaan, dan kemitraan sekaligus menunjukkan bahwa lelaki sendiri atau suami sendiri belumlah sempurna, demikian juga perempuan, sebelum menyatu dengan pasangannya yang juga sebagian. Baik laki-laki maupun perempuan, lahir dari sebagian keduanya, yaitu perpaduan antara sperma laki-laki dan sel telur perempuan. ${ }^{42}$

Kesetaraan antara laki-laki dan perempuan dalam konteks perkawinan juga dapat dilihat dengan adanya hak dan kewajiban

40 Muḥammad bin Yazīd Abu Abdillah, Sunan Ibn Mājah, (Bairūt: Dār al-Fikr, tt), 602.

41 Rustam Dahar Karnadi AH, "Kesetaraan Laki-Laki Dan Perempuan Dalam Hukum Perkawinan Islam", SAWWA 8: 2 (April 2013), 361386

42 Lihat, M. Quraish Shihab, Perempuan... 
yang harus dilaksanakan dan dipenuhi oleh masing-masing pihak. Pemenuhan hak oleh masing-masing pihak suami maupun istri setara dengan beban kewajiban yang harus ditunaikan oleh masing-masing pihak (suami-istri). Tidak ada yang saling mendominasi dan menguasai pasangannya, namun sebagai mitra sejajar yang saling menghargai, saling menghormati, saling mengisi dan menyempurnakan satu sama lainnya.

\section{Prinsip Mu'asyarah bi al-Ma'rūf}

Prinsip ini didasarkan kepada firman Allah Swt.,:

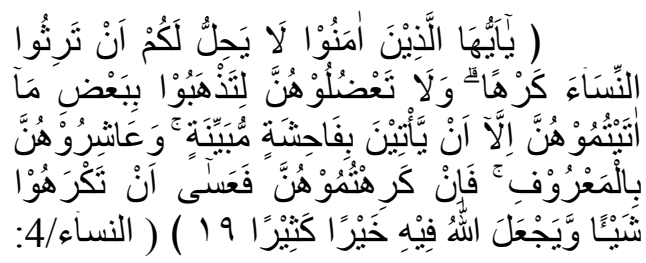

"Wahai orang-orang beriman! Tidak
halal bagi kamu mewarisi perempuan dengan jalan paksa dan janganlah kamu menyusahkan mereka karena hendak mengambil kembali sebagian dari apa yang telah kaтu berikan kepadanya, kecuali apabila mereka melakukan perbuatan keji yang nyata. Dan bergaullah dengan mereka menurut cara yang patut. Jika kamu tidak menyukai mereka, (maka bersabarlah) karena boleh jadi kamu tidak menyukai sesuatu, padahal Allah menjadikan kebaikan yang banyak padanya." (QS. An-Nisā'/4:19)

KH. Husein Muhammad mendefinisikan mu'āsyarah bi al-ma'rūf sebagai "pergaulan, pertemanan, persahabatan, kekeluargaan, dan kekerabatan yang di-bangun bersama (antara suami isteri) dengan cara-cara yang baik, yang sesuai dengan tradisi dan situasi masyarakatnya masing-masing, namun tidak bertentangan dengan norma agama, akal sehat, maupun fitrah manusia. $^{43}$

Walaupun dalam konteks ayat di atas, perintah tersebut ditujukan kepada seorang suami untuk mempergauli istrinya secara baik, maka apabila menggunakan metodologi mubādalah maka ketentuan tersebut juga

43 Husein Muhammad, Fiqh Perempuan, (Yogyakarta: LkiS, 2007 ), 146. berlaku kepada seorang istri, untuk mempergauli suami secara baik pula.

Pergaulan yang baik menurut Syaikh Nawawi adalah baik menurut syara', yakni perbuatan sikap dan tutur kata. Suami diperintahkan untuk bersikap lemah lembut, tidak mudah marah, menyenangkan istrinya dan menuruti kehendak istrinya dalam hal kebaikan. ${ }^{44}$ Pun demikian, seorang istri juga harus bersikap yang sama kepada suaminya.

Mengenai Mu'āsyarah bi al-Ma'rūf, selain diartikan dengan sikap lemah lembut dan tutur kata yang baik, Syaikh Nawawi mengartikan lafaz ma'rūf dengan kata adil dalam hal menginap (pembagian waktu giliran bagi yang berpoligami), nafkah, dan termasuk bertutur kata yang baik. ${ }^{45}$

Senada dengan Syaikh Nawawi, Faqihuddin mengatakan bahwa mu'āsyarah bi al-ma'rūf tidak semuanya demikian. Memang dalam bergaul antara suami dan istri diharuskan untuk bersikap adil, berperilaku baik, bersikap lemah lembut, saling menyenangkan satu sama lain dan tidak saling menyakiti. Pergaulan yang baik dalam hubungan suami istri adalah hubungan yang dilandasi ketakwaan dan kemaslahatan. ${ }^{46}$

\section{Prinsip Musyawarah}

Prinsip ini didasarkan pada firman Allah Swt.,

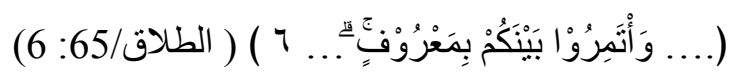

"..dan musyawarahkanlah di

antara kamu (suami-istri) (segala sesuatu) dengan baik... (QS. AtȚalaq/65:6)

Suami dan istri merupakan dua jenis kelamin yang berbeda, yang memiliki pemikiran dan keinginan yang berbeda. Apabila hal tersebut tidak mampu dikelola dengan baik, maka didalam rumah tangga akan senantiasa ada perselisihan diantara keduanya.

44 Muhammad Nawawi Al-Bantani, Murāh Labīdz, (Beirut: Dār Ma'rifat al-'Ilmiyyah, Tt), 135.

45 Muhammad Nawawi Al-Bantani, Murāh Labīdz, 135.

46 Faqihuddin Abdul Kodir, Manba'asSa'ādah, (Cirebon:Fahmina Institute, 2013), 23. 
Pernikahan yang melahirkan mawaddah dan rahmah adalah pernikahan yang didalamnya kedua pasangan mampu berdiskusi menyangkut segala persoalan yang mereka hadapi, sekaligus keluwesan untuk menerima pendapat pasangannya. Penilaian yang tulus dan tidak menilainya sebagai mengurangi kehormatan yang menerimanya ${ }^{47}$. Hal itulah yang senantiasa dilakukan dan dicontohkan Rasulullah Saw dalam kehidupan rumah tangganya. Hal ini sebagaimana sebuah riwayat yang dituturkan oleh Imam Bukhari:

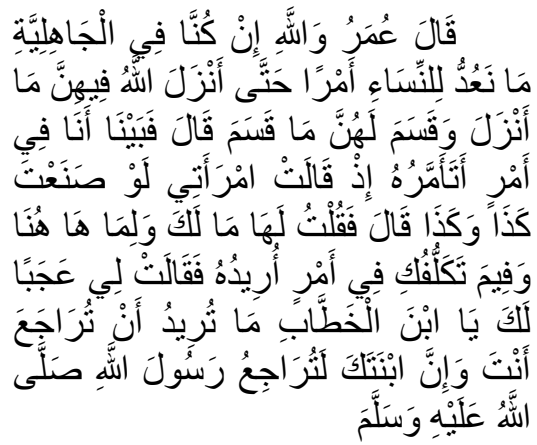

"Telah berkata Umar bin Khatțab, "Di masa Jahiliyah, kami tidak pernah mengikut sertakan wanita dalam suatu urusan, sehingga telah tiba waktunya Allah Swt., menentukan kedudukan dan peranan mereka, dia (Umar) melanjutkan: "Tatkala saya sedang memikirkan suatu urusan, tiba-tiba istriku berkata; Bagaimana kalau kamu buat seperti ini dan seperti itu? Lalu kukatakan padanya; Mana mungkin kamu tahu? Kamu tidak usah ikut campur dan susah-susah memikirkan urusanku. Maka dia berkata kepadaku; Sungguh aneh kamu wahai Ibnul Khaththab, kamu tidak mau bertukar pikiran denganku! Padahal putrimu selalu bertukar pikiran dengan Rasulullah Saw." 48

Dengan bermusyawarah bersama pasangan (suami/istri) dalam setiap masalah dan keinginan dapat memperkaya paradigma dari sudut pandang yang berbeda, sehingga setiap keputusan yang diambil dilakukan dengan penuh kesadaran dengan berbagai manfaat dan akibat yang ditimbulkan dari keputusan tersebut.

47 M. Quraish Shihab, Perempuan... 150

48 Muhammad bin Ismail Abu 'Abdillah alBukhari, Al-Jāmi’ al-Șahīh, 4532.

\section{Prinsip Saling Menerima}

Didalam al-Qur'an prinsip tersebut dengan istilah (عَنْ تَرَاض مَّنْهُمَاضِ), yaitu adanya penerimaan/ kerelaan diantara dua pihak (suami dan istri). Masing-masing pasangan saling menerima tidak hanya dari segi kelebihan pasangannya, namun juga segala kekurangan pasangannya dan juga menyadari kekurangan dan kelebihan yang dimilikinya sendiri. Dengan prinsip ini maka masing-masing pihak tidak ada yang merasa sempurna, sehingga tidak memunculkan rasa gumede (sombong) atas pasangannya. Dan dengan prinsip ini pula memunculkan kesadaran bahwa keduanya saling menyempurnakan kekurangan pasangannya dengan kelebihan yang dimilikinya. Hal ini sebagaimana firman Allah Swt.,

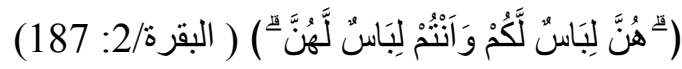

$$
\begin{aligned}
& \text { Mereka (istri-istri kamu) adalah }
\end{aligned}
$$

Kalau pakaian berfungsi menutup aurat dan kekurangan jasmani manusia, demikian pula pasangan suami dan istri, keduanya saling melengkapi dan menutupi pasangannya masing-masing. Kalau pakaian merupakan hiasan bagi pemakainya, suami adalah hiasan bagi istrinya, demikian pula sebaliknya. ${ }^{49}$

\section{H. MENYEMAI PRINSIP PERKAWINAN, MEMINIMALISIR PERCERAIAN}

Perkawinan sebagaimana yang dikatakan dalam UU No. 1 tahun 1974 yaitu sebagai ikatan lahir bathin antara seorang pria dengan seorang wanita sebagai suami isteri dengan tujuan membentuk keluarga yang bahagia dan kekal berdasarkan Ketuhanan Yang Maha Esa.

Namun dalam realitasnya upaya mewujudkan keluarga yang bahagia dan kekal tidak semudah membalikan telapak tangan, karena dalam keluarga pasti dan akan diuji dengan berbagai macam permasalahan dan persoalan. Dan tidak jarang pasangan suami istri menjadikan perceraian sebagai solusi

${ }^{49}$ M. Qurais Shihab, Pengantin al-Qur'an, 94 
terakhir dalam menyelesaiakan persoalan tersebut. Berdasarkan data perceraian yang penulis peroleh dari Statistik Perkara Pengadilan Agama Se-Jawa Barat melalui portal Kabayan, yang penulis akses pada hari Rabu tanggal 17 Maret 2021 dimana pada tahun 2020 terdapat 102.161 kasus dengan rincian kasus cerai gugat sebanyak 76.388 kasus, sedangkan cerai talak 25.773 kasus. Untuk tahun 2021 sendiri per Maret 2021 terdapat 26744, dengan kasus Cerai Gugat 20348 kasus, dan cerai talak $6396^{50}$.

Dilihat dari kasus penyebab tingginya angka perceraian pada tahun 2020, tertinggi disebabkan karen faktor adanya peselisihan dan pertengkaran terus menerus dengan jumlah 48.448, kemudian disusul karena faktor ekonomi dengan 40510 kasus, dan karena faktor meninggalkan salah satu pihak dengan jumlah 3.978, sedangkan karena kekerasan dalam rumah tangga dengan jumlah 376 kasus.

Jumlah angka perceraian dengan berbagai faktor penyebab tersebut tentu menjadi keprihatinan bagi kita, karena perkawinan dimana seharusnya dapat bertahan dengan penuh kebahagiaan, namun harus putus ditengah jalan. Hal ini tentunya harus ada upaya untuk meminimalisir angka perceraian, agar dampak negatif yang muncul dari perceraian dapat dihindari.

Faktor penyebab perceraian sebagaimana yang terdapat pada data tersebut, apabila dianalisis dengan menggunakan paradigma prinsip-prinsip perkawinan Islam dapat dikatakan bahwa pengejawantahan prinsipprinsip perkawinan sebagaimana yang telah digariskan al-Qur'an maupun Sunnah tidak terimplementasikan secara menyeluruh dalam kehidupan rumat tangga.

Perceraian karena Faktor perselisihan dan pertengkaran terus menerus menunjukkan bahwa prinsip musyawarah tidak berjalan secara maksimal. Karena dalam kehidupan keluarga, prinsip musyawarah, terutama antara suami isteri, merupakan sesuatu yang perlu diterapkan. Sesuai dengan prinsip bahwa tak

\footnotetext{
50http://kabayan.ptabandung.go.id/pengawa san sipp/proses stat. Diakses pada hari Rabu, 17 Maret 2021
}

ada suatu masalah yang tak dapat diselesaikan, selama prinsip musyawarah diamalkan. Dalam hal ini dituntut sikap terbuka, lapang dada, jujur, mau menerima dan memberi serta sikap tidak mau menang sendiri dari pihak istri ataupun suami. Sikap suka bermusyawarah dalam keluarga dapat menumbuhkan rasa memiliki dan rasa tanggung jawab di antara para anggota keluarga dalam menyelesaikan dan memecahkan masalah-masalah yang timbul. $^{51}$

Sedangkan perceraian karena sebab faktor ekonomi kerap sekali terjadi, di dalam Undang- Undang bahwa suami wajib memberikan nafkah, kiswah, dan tempat tinggal bagi istri, kemudian suami wajib memberikan biaya perawatan dan pengobatan bagi istri apabila ia sakit. Sebagaimana yang telah penulis paparkan di atas, bahwa salah satu prinsip perkawinan adalah saling menerima, maka dalam konteks ini, ketika suami sudah berusaha semaksimal mungkin dalam mencari nafkah, maka istri bersikap bijak dan menghargai usaha dari suami karena sudah berjuang semaksimal mungkin dalam mencari nafkah untuk istri dan anak-anaknya, yakni dengan bersikap qana'ah. Berbeda halnya apabila seorang suami bersikap bermalasmalasan dalam mencari nafkah, sekalipun berdalih beribadah kepada tuhannya. Islam tidak membenarkan meminta-minta tanpa mencucurkan keringatnya padahal sejatinya ia mampu untuk bekerja.

Perceraian karena faktor meninggalkan salah satu pihak, merupakan sikap tidak bertanggung jawab. Sikap ini menunjukkan bahwa pelaku tidak mengimplementasikan semua prinsip-prinsip perkawinan yang penulis paparkan di atas. Oleh sebab itu, upaya yang tepat untuk menanggulangi faktor ini adalah dengan dimaksimalkannya bimbingan pra nikah oleh KUA.

Dalam konteks ini, apapun bentuk permasalahannya yang muncul dalam rumah tangga sangat rentan terjadinya perceraian

51 Ardianto, "Konsepsi Bangunan Keluarga Sakinah Bagi Pasangan Suami Istri Yang Telah Bercerai Pada Masyarakat Muslim di Kota Manado", Jurnal Ilmiah Al-Syir'ah 15:1 (Juni 2017), 1-13 
apabila rumah tangga yang dibangun tanpa dilandasi pilar-pilar yang mengukuhkan dan mengokohkan rumah tangga tersebut. Dalam hal ini, Kang Faqih menyebutkan lima pilar rumah tangga, yaitu: Pertama, pilar komitmen terhadap perjanjian diantara kedua belah pihak yang termanifestasikan dalam akad nikah. Kedua, pilar saling menyempurnakan dan membutuhkan satu sama lainnya. Ketiga, pilar saling memperlakukan satu sama lainnya dengan baik (mu'āsyarah bi al-ma'rūf). Keempat, pilar saling bermusyawarah dalam memutuskan sesuatu terkait dengan rumah tangga. Kelima, Pilar saling merasa nyaman dan memberi kenyamanan kepada pasangan ${ }^{52}$. Kelima pilar tersebut merupakan landasan kokoh bagi pasangan suami istri dalam mengarungi bahtera rumah tangga untuk menggapai tujuan perkawinan yang dikehendaki al-Qur'an dan telah ditauladankan oleh Nabi Muhammad Saw.

\section{I.KESIMPULAN}

Dalam menyalurkan hasrat seksual, juga untuk mewujudkan rasa sakinah, mawaddah, dan rahmah. Upaya mewujudkan hakikat perkawinan yang digariskan al-Qur'an tersebut dengan ditetapkannya sederet prinsip-prinsip perkawinan yang tertuang dalam nas al-Qur'an dan Hadis sebagai pedoman bagi pasangan suami istri dalam membentuk keluarga yang bahagia, yang dihiasi ketenangan jiwa dan raga, serta sebagai tempat mencurahkan dan berbagi rasa kasih dan sayang.

Pengimplementasian prinsip-prinsip perkawinan yang diberikan Islam, baik yang tersurat maupun tersirat didalam kehidupan rumah tangga, merupakan pedoman dan ikhtiar umat Islam dalam mewujudkan rumah tangga sakinah, mawaddah, dan rahmah serta kekal sampai maut memisahkan. Sehingga diperlukan upaya membumikan prinsip tersebut melalui sederet kebijakan pemegang kebijakan (pemerintah) untuk memahamkan dan mengimplementasikan nilai-nilai tersebut kepada rakyatnya, khususnya umat Islam, agar angka perceraian dapat diminimalisir.

$5^{2}$ Lihat, Faqihuddin Abdul Kodir, Qirā’ah Mubādalah...343-357

\section{DAFTAR PUSTAKA}

Buku

Abdul Kodir, Faqihuddin. Manba'as-Sa'ādah. Cirebon:Fahmina Institute, 2013. Qirā'ah Mubādalah:

Tafsir Progresif untuk Keadilan Gender dalam Islam. Yogyakarta: IRCiSoD, 2019.

Abu 'Abdillah al-Bukhari, Muhammad bin Ismail. Al-Jāmi' al-Șahīh al-Mukhtașar. Beirut: Dār Ibn Katsīr, 1987.

Abū al-Husaini. Shahīh Muslim. Beirut: Dār alKutub al-'Ilmiyah, 1998.

Al Ghandur, Ahmad. Al-Ahwwāl Al-Syakhșiyyah fì al-Tasyrī' al-Islāmy. Kuwait: Maktabah Al Falāh, 2006.

al-Jazīrī, Abd al-Raḥmān. Al-Fiqh 'alā alMadhāhib al-Arba'ah. Beirut: Dār alKutub al-'Ilmiyah, 2011.

al-Zuhāilī, Wahbah. al-Fiqh al-Islāmī wa Adillatuh. Damaskus: Dār al-Fikr, 2004. al-Tafsìr al-Munīr fi al'Aqīdah wa al-Shari'ah wa al-Manhaj. Damaskus: al-Fikr al-Mua'āṣir, 1418.

Amin Suma, Muhammad. Hukum Keluarga Islam di Dunia Islam. Jakarta: PT.Raja Grafindo Persada, 2004.

Azis Dahlan, Abdul. et.al, Ensiklopedi Hukum Islam. Jakarta: Ichtiar Baru van Hoeve, 1996.

Ḥajar al-'Asqalānī, Ibnu. Bulūghu al-Marām. Surabaya: Maktabah Dar al-Ihya al'Arabiyah, 1352.

Kașīir, Ibn. Tafsīr al-Qurān al- 'Aẓimm. Kairo: Dār al-Hadits, 2010.

Muhammad, Husein. Fiqh Perempuan. Yogyakarta: LKiS, 2007.

Nawawi Al-Bantani, Muhammad. Murāh Labīdz. Beirut: Dār Ma'rifat al-'Ilmiyyah, Tt.

Shihab, M. Quraish. Pengantin al-Qur'an: Kalung Permata Buat Ank-Anakku. Jakarta: Lentera Hati, 2007.

Perempuan:Dari cinta Sampai Seks, Dari Nikah Mut'ah sampai Nikah Sunnah, Dari Bias Lama sampai Bias Baru. Jakarta: Lentera Hati, 2007. 

- Wawasan Al-Qur'an: Tafsir

Maudhui atas Pelbagai Persoalan Umat. Jakarta, Mizan; 1996.

Subhan, Zaitunah. Membina Keluarga Sakinah. Yogyakarta; Pustaka Pesantren, 2004.

Warson Al-Munawwir, Ahmad. Kamus AlMunawwir Arab-Indonesia Terlengkap. Yogyakarta: Pustaka Progressif, 1997.

Yazīd Abu Abdillah, Muhammad bin. Sunan Ibn Mãjah. Bairūt: Dār al-Fikr, tt.

Zahid, Moh. Dua Puluh Lima Tahun Pelaksanaan Undang-Undang Perkawinan. Jakarta: Departemen Agama RI Badan Litbang Agama dan Diklat Keagamaan, 2002.

\section{Jurnal Ilmiah}

Ardianto, "Konsepsi Bangunan Keluarga Sakinah Bagi Pasangan Suami Istri Yang Telah Bercerai Pada Masyarakat Muslim di Kota Manado", Jurnal Ilmiah AlSyir'ah 15:1 (Juni 2017).

Atabik dan Khoridatul Mudhiiah, Ahmad. "Pernikahan Dan Hikmahnya Perspektif Hukum Islam". Yudisia 5: 2 (Desember 2014).

Dahar Karnadi A.H, Rustam. "Kesetaraan Laki-Laki Dan Perempuan Dalam Hukum Perkawinan Islam", SAWWA 8: 2 (April 2013).

Najwah, Nurun. "Kriteria Memilih Pasangan Hidup (Kajian Hermeneutika Hadis)", Jurnal Studi Ilmu-Ilmu al-Qur'an dan Hadis 17: 1 (Januari 2016).

Yunus Shamad, Muhammad. "Hukum Pernikahan Dalam Islam". Istiqra' 5:1 (September 2017).

\section{Website}

http://kabayan.pta-

bandung.go.id/pengawasan_sipp/proses_stat.

Diakses pada hari Rabu, 17 Maret 2021 